\title{
TITLE:
}

\section{HIS MAJESTY THE EMPEROR OF JAPAN AND BIOLOGY}

$\operatorname{AUTHOR}(S)$ :

Tomiyama, Itiro; Tsujimura, Hatsuki

\section{CITATION:}

Tomiyama, Itiro ...[et al]. HIS MAJESTY THE EMPEROR OF JAPAN AND BIOLOGY. PUBLICATIONS OF THE SETO MARINE BIOLOGICAL LABORATORY 1973, 20: 7-10

\section{ISSUE DATE:}

1973-12-19

URL:

http://hdl.handle.net/2433/175794

RIGHT: 


\title{
HIS MAJESTY THE EMPEROR OF JAPAN AND BIOLOGY
}

\author{
ITIRo TOMIYAMA and HATSUKI TSUJIMURA \\ Biological Laboratory, Imperial Household, Tokyo, Japan
}

It is well known that His Majesty the Emperor of Japan has been much interested in animals and plants from his youth, and we hear that it was 1925 when his Biological Laboratory was erected and he began to study biology under the guidance of the late Dr. Hirotaro HATTORI. Since then, he has continued to study, availing himself of the leisure time spared from his duties. Once he has studied heredity, but he now lays stress on the classification of animals and plants in his studies.

For His Majesty's field works, the three imperial villas, respectively in Nasu, Hayama, and Suzaki, have been indispensable.

The Nasu Villa is situated at the foot of Mt. Nasu, and its grounds are extensive, hilly, and with many streams flowing through the wood; the vicinity known as the Nasu district is a summer resort to the north of Tokyo.

His Majesty examined almost all mucus fungi growing within the grounds and in its vicinity. The results of this study were published by Dr. HATTORI in the "Myxomycetes of Nasu District" in 1935, and its revised edition by the same author in 1964, a few years before his death.

During his stay at the Nasu Villa, weather permitting, His Majesty very often accompanied by Her Majesty, made it a rule to go up and down the forests and open fields of the grounds and its vicinity to collect specimens for his studies and to take notes of the flowering and fruiting times and other ecological facts of all kinds of plants, or sometimes to visit marshes or highlands lying remote from his villa by car for the same purpose. In this way, data have been gradually accumulated, but a confusion began to appear in his researches, because many intermediate or variant forms were found existing among his specimens. Thereupon, the representatives of the plants were sent to respective specialists for exact identification, and then these specialists were invited all together to the villa every summer to stay there for several days to go out for observations along with His Majesty. Following their field work, lively and timely discussions on the plants in question and various botanical problems were held, once or twice each time, in the presence of His Majesty. Under such circumstances, the following three books were published: "Flora Nasuensis" in 1962, its "Additions and Emendations" in 1963, and "Nova Flora Nasuensis" in 1972.

One may be interested or feel strange to see that these books are anonymous. It is said that His Majesty refused to become the sole author of these books, because he had given due regard to those specialists who not only identified many of the plants but also added certain expert remarks in books. On the other hand, the 
specialists insisted that they had helped him too little in writing up the manuscripts neatly to be called as joint authors. Eventually, these books were mentioned only "Edited by the Biological Laboratory, Imperial Household". At any rate, the books are highly appreciated in Japan for the detailed ecological accounts of the plants of the Nasu district and for an advanced information about distributions of Japanese plants given in them.

Several times a year from winter to early summer, His Majesty used to stay at the Hayama Villa, in the town of Hayama facing the eastern part of Sagami Bay, and to go out on the sea on board the dredging boat, quite often accompanied by Her Majesty, when he could be at leisure and the sea was calm. In the warmer season, he tried to collect marine animals on the shore near the villa. The animals thus obtained were sent to his Biological Laboratory in Tokyo to be examined by himself one by one before they were kept as specimens in the Laboratory Museum. Whenever he found any difficulties in identifying any of these animals, exclusive of hydroids, he sent it to a specialist of the animal concerned, asking for professional identification.

In this way, the faunal knowledge of Sagami Bay was advanced gradually, and monographs of some animal groups were written by specialists one after another on the basis of His Majesty's specimens as follows: "Opisthobranchia of Sagami Bay" by Dr. K. BABA in 1949, its "Supplement" by the same author in 1955, "Ascidians of Sagami Bay" by Dr. T. TokiokA in 1953, "The Crabs of Sagami Bay" by Dr. T. SAKAI in 1965, "Hydrocorals and Scleractinian Corals of Sagami Bay" by Dr. M. EGUCHI in 1968, "The Sea Shells of Sagami Bay" by Drs. T. Kuroda, T. Habe and K. Oyama in 1971. Another monograph, "The Star-fishes of Sagami Bay" by Dr. R. HAYASHI, is now in press.

As for marine hydroids, His Majesty, in the early years of his long study, sent some specimens to such specialists home and abroad as Drs. T. UCHIDA, E. STECHOW, E. Leloup, L. M. Fraser and A. K. Totton, as he was doing with the plants from the Nasu district and other marine animals from Sagami Bay, and actually several papers dealing with those specimens were published by them. Later, however, he has continuously devoted himself to the classification of hydroids and published the following three papers: "A Review of the Hydroids of the Family Clathrozoidae with Description of a New Genus and Species" in 1967, "Some Hydroids of the Amakusa Islands" in 1969, "Additional Notes on Clathrozoon wilsoni SPENCER" in 1971.

Two other papers, "On the Hydrozoans from the Bonin Islands" and "A Review of the Hydroids of the Family Solanderiidae of Sagami Bay", are now being prepared to be printed, as seen in the abstracts given below.

Since the main building of the Hayama Villa was burnt down in 1970, the Suzaki Villa has been used by His Majesty instead of the Hayama Villa. The Suzaki Villa was built recently near the southern end of Izu Peninsula embracing Sagami Bay westerly.

His Majesty's biological investigations are still now carried on continuously. 
We hope that many other papers on hydroids by His Majesty himself and monographs of other animal groups of Sagami Bay by respective specialists will be published one after another in the future.

\section{Abstracts of His Majesty's Papers to be Published}

\section{On the Hydrozoans from the Bonin Islands}

After observing many hydroid specimens, which were collected by Dr. M. ImAJIMA, National Science Museum, from the Bonin Islands, His Majesty assigned them to 28 species. Additionally, some other specimens collected by His Majesty from Sagami Bay and other localities in Japan, and a few foreign specimens were examined for observation of the variation or of the gonotheca of some of the species. A single milleporid colony collected by His Majesty from Haha-jima, an island of the Bonin Islands, was also examined.

List of the species studied:

Class HYDROZOA

Order HYDROIDA

Suborder ATHECATA

Family HALOCORDYLIDAE

1. Halocordyle disticha (GoLDFuss)

Family EUDENDRIIDAE

2. Eudendrium sp. Fragmentary specimens only.

Suborder THECATA

Family HALECIIDAE

3. Halecium sessile Norman

4. Halecium tenellum HiNcKs

5. Hydrodendron caciniformis (RITCHIE), new to Japan.

Family CAMPANULARIIDAE

6. Clytia linearis (THORNELY)

7. A campanulariid species. A fragmentary specimen only.

Family LAFOEIDAE

8. Hebella calcarata (A. AGASSIZ)

Family SERTULARIIDAE

9. Calamphora campanulata (WARREN), new to Japan.

10. Dynamena crisioides LAMOURoux

11. Dynamena obliqua LAMouroux

12. Dynamena sp. This hydroid is probably new to science. The colony is very small and attains a height of about $2.5 \mathrm{~mm}$. This species resembles $D$. densa (STECHOw) to some extent, but is distinguished from the latter by the different shape of the gonotheca.

13. Sertularella minuscula Billard, new to Japan.

14. Sertularella tenella (ALDER)

15. Sertularia ligulata THORNELY. The hydranth has a dactylozooidal organ (THORNely's tongue or strap). The male and female gonothecae are seen in the specimens from Sagami Bay. The hydroid, ever known as Sertularia turbinata Rirchie (not of LAMOuRoux) from Japan, belongs to this species probably.

16. Thyroscyphus fruticosus (ESPER), new to Japan. Further investigations on the specimens with gonothecae are wanted.

17. Tridentata $\mathrm{sp}$. Sterile colonies. The hydranth is seemingly devoid of blind sac. Family PLUMULARIIDAE

18. Aglaophenia suensoni JÄDERHOLM 
19. Antennella secundaria (GMELIN)

20. Antennella sp. A fragmentary specimen only.

21. Heterotheca buski (BALE), new to Japan. The male and female gonothecae are observed in the specimens from Sagami Bay.

22. Heterotheca campanula (BUSK)

23. Monostaechas quadridens (MCCRADY)

24. Monotheca flexiosa (BALE), new to Japan.

25. Plumularia alicia Torrey, new to Japan. The colonies examined (less than $20 \mathrm{~mm}$ in height) are much lower than TORREY's types (3-5 inches).

26. Plumularia setacea (LinNAEUs)

27. Plumularia strictocarpa var. japonica SteCHOW and UCHIDA. Further investigations are wanted, because this variety was reported originally from Mutsu Bay, which is affected very weakly by a warm current through the Japan Sea, but the Bonin Islands are washed always by tropical waters.

28. Ventromma halecioides (ALDER), new to Japan. Three colonies without gonothecae and a few Venezuelan colonies with male gonothecae are observed.

\section{Order HYDROCORALLINA}

Suborder MILLEPORINA

Family MILLEPORIDAE

29. Millepora platyphylla HeMPRICH and EHRENBERG

\section{A Review of the Hydroids of the Family Solanderiidae of Japan}

The synopses of the family, genera and species, and the keys to the genera and species are given. Three species, Solanderia misakiensis (INABA), S. secunda (INABA) and a Rosalinda species are dealt with.

Colonies of these three species are arborescent and resemble one another in shape. Their stems, branches and branchlets consist of chitinous spongy skeleton. The hydranths are provided with a whorl of capitate tentacles, and arranged in two rows in Solanderia misakiensis and secunda but scattered in the Rosalinda sp. The gonophores are eumedusoid sporosacs.

1. Solanderia misakiensis (INABA).

2. Solanderia secunda (INABA). This hydroid is distinguished principally from misakiensis in having a pair of low skeletal processes which flank the hole for each hydranth.

3. Rosalinda sp. This hydroid is probably new to science. The colony attaches to and grows on an arborescent colony of other hydroids or octocorals and extends beyond the tips of branchlets of the substratum. A pair of skeletal processes, as seen in Solanderia secunda, are absent.

The gonophores of this species arise from the proximal part of a hydranth, whereas those of Solanderia spp. arise directly from the coenosare of skeleton.

This species is known from Sagami Bay only and seems to be less common than Solanderia misakiensis and secunda in Sagami Bay.

For this species, a different genus may be erected, if the gonophore of Rosalinda williami Totron, the type species of the genus Rosalinda, is found arising from other part. 